\title{
Racial Ideologies, State Bureaucracy, and Decolonization in Bolivia
}

\author{
Marcelo A. Bohrt \\ American University
}

\begin{abstract}
Race has shaped the development of the Bolivian state and its institutions albeit with important transformations in the social and political meaning of race. This paper discusses the racialization of the central state bureaucracy in Bolivia along these two dimensions: the distribution of bureaucratic resources and the assumptions and meanings that underpin bureaucratic hierarchy and spaces. It first discusses the relationship between the modern state and the concept of race, and conceptualizes the ethnoracial bureaucracy as a material and symbolic structure. Next, it examines the composition of the public administration sector overall and across the bureaucratic hierarchy in 2001, before the MAS-IPSP's rise to power. Last, it surveys the narratives of race and nation that Creole and white-mestizo state elites historically mobilized in demarcating the boundaries of state power around whiteness. In contemporary Bolivia, the production of alternative official narratives of race and nation seeks to blur the boundary between indigeneity and statecraft (re)produced since the early republican period, and to legitimize the changing ethnoracial composition of the bureaucracy. The durability of the project is not guaranteed as the sediment of history and competing political projects weighs heavy on this process of transformation and negotiation.
\end{abstract}

Keywords

Bureaucracy, decolonization, race, racial ideologies, State 


\section{Resumen}

Si bien el significado social y político de la raza en Bolivia ha atravesado transformaciones significativas, esta ha configurado el desarrollo del Estado y sus instituciones. Este artículo examina la racialización del aparato burocrático central del Estado boliviano en torno a dos dimensiones: la distribución de recursos burocráticos y los significados y supuestos que sustentan las jerarquías y los espacios burocráticos. La primera parte aborda la relación entre el Estado moderno y el concepto de raza, y conceptualiza la burocracia etnoracial como una estructura material y simbólica. Segundo, el estudio investiga la composición de la administración pública en general y en los diferentes niveles de la jerarquía burocrática en el año 2001, antes de la llegada del MAS-IPSP al poder. En la última parte, se indagan las narrativas de raza y nación que las élites estatales criollas y blanco-mestizas movilizaron históricamente para demarcar los límites del poder estatal en torno a la blanquitud. La producción de nuevas narrativas oficiales de raza y nación en la Bolivia contemporánea busca difuminar el límite entre la indigeneidad y el Estado, (re)producido desde los primeros períodos republicanos, así como legitimar la composición étnico-racial cambiante del aparato burocrático. No existen garantías para la durabilidad de este proyecto, pues los sedimentos históricos y la competencia entre diversos proyectos políticos pesan en este proceso de transformación y negociación.

\section{Palabras claves}

Burocracia, descolonización, Estado, ideologías raciales, raza

The colonial composition of the state apparatus and the urgency to dismantle all the explicit and implicit mechanisms that connote and denote this coloniality is due to the fact that it is engrained in the State structure and its quotidian workings. The continuous construction of the colonial penetrated all social spheres and in them converged elements of domination, ethnic exclusion, racism and hegemony, mystified by the liberal and neoliberal modernization of certain segments of society. [...] The political institutionality and constitution of the Executive Branch have a colonial base, as such, it is necessary to dismantle colonialism by changing the [old] state institutionality for a new one.

PND (Plan Nacional de Desarrollo) 2007, 15 (Author's translation) 


\section{Introduction}

Almost forty years ago, political scientist Cynthia H. Enloe wrote, "[i]n Latin America almost by definition an Indian (of whatever particular ethnic group) has to slough off his Indian-ness in order to gain access into a bureaucracy. Where Indians as Indians are found in Andean and Mexican bureaucracies they are clustered at the lowest levels" (Enloe 342). Enloe's observation points to two dimensions of the racialization of state bureaucracy in the region: the distribution of bureaucratic resources and the assumptions and meanings that underpin bureaucratic hierarchy and spaces. In this paper, I discuss the racialization of the central state bureaucracy in Bolivia along these two dimensions. I then argue that in twenty-first century Bolivia the production of alternative official narratives of race and nation seeks to blur the boundary between indigeneity and statecraft (re)produced since the early republican period, while providing a coherent narrative to legitimize the changing ethnoracial composition of the bureaucracy.

Race $^{1}$ has shaped the development of the Bolivian state and its institutions since the colonial period albeit with important transformations in the social and political meaning of race. It has historically shaped membership in the state, but also who could hold and exert state power. As historian Herbert Klein notes, the efforts of a white Spanish-speaking and Westernoriented elite in an indigenous-majority country to maintain its monopoly over state power against cholo and Indians ${ }^{2}$ shaped Bolivia's political development. Criollo and, later, white-mestizo state elites understood and represented themselves as the embodiment of modernity and natural holders of state authority. They simultaneously rationalized control of the central bureaucracy through discourses that variously casted indigeneity as backward, unfit, and/or dangerous. The Indian question -or how to incorporate a purportedly 'backward' indigenous population into 'modern' national life- has been perennially present in their state building projects (Klein).

Patterns of political exclusion and incorporation along race/ethnicity ${ }^{3}$ and class in Bolivia have changed over nearly two centuries as a result of social

\footnotetext{
1 Like in much of the Andes, racial categories in this national context have been understood and defined in terms of cultural difference, placing indians, cholos, mestizos, and whites along a ladder between barbarism and civilization (Gotkowitz).

2 Indio is a colonial racial category that lumps together native Andean peoples (Postero).

${ }^{3}$ I view race and ethnicity as overlapping analytic concepts in that "both race and ethnicity involve a discourse about origins and about the transmission of essences across
} 
mobilization for equality, rights, and recognition (Postero). Most recently, the turn of the century brought about an epochal transformation in ethnoracial relations (Kohl and Bresnahan). In this context, new social movements and politicians have put the issue of bureaucratic exclusion at the center of political debate. In fact, the Morales administration and its allies conceived the transformation of bureaucratic practice and the bureaucratic corps as a central step in the broader decolonization agenda. As the opening quote reveals, the administration's state decolonization project problematized more than the ethnoracial composition of the central state bureaucracy. It articulated a radical critique of the racial foundations of the bureaucracy, problematizing dominant narratives of race and nation that underpinned the naturalization of state power in white-mestizo bodies and the exclusion of indigenous people from state spaces.

This paper is organized in four sections. First, I discuss the relationship between the modern state and the concept of race, and conceptualize the ethnoracial bureaucracy as a material and symbolic structure. Second, I examine the composition of the public administration sector overall and across the bureaucratic hierarchy in 2001, before Evo Morales and the MAS-IPSP's rise to power. Third, I discuss the narratives of race and nation that Creole and white-mestizo state elites historically mobilized in demarcating the boundaries of state power around whiteness. Lastly, I discuss the changing narratives of race and nation through which the Morales administration and decolonization proponents have mobilized since 2006 to contest the racialization of the bureaucracy.

\section{The Ethnoracial Bureaucracy}

Exclusion from the state bureaucracy has been one of the central grievances of identity movements that have sought to challenge ethnoracial subordination across the Americas. International organizations have also advocated for the construction of representative bureaucracies, linking diversity to governance and democratic legitimacy (Htun). After all, modern nation-states offer their members symbolic and material resources and denies them to others both outside and within its boundaries (Wimmer). The emergence of ethnoracial movements and conflict reflects the ethnicization of

generations" (Wade 20). However, to reduce race to ethnicity is, as Peter Wade argues, "to blur the particular history by which these [racial] identifications come to have the force they do" (Wade 19, emphasis in the original). 
the state bureaucracy, whereby ruling elites distribute rights and resources exclusively through their ethnoracial networks (Wimmer).

The relationship between race/ethnicity and state, however, is not limited to state's role in race-making and racial stratification in society. State organizations are not exempt from cultural dynamics within, as dominant theories of public administration assume (for a discussion see Maravić et al.). Rather, political institutions are founded on historically situated systems of meaning and practices, or cultural formations (Steinmetz). Thus, it is necessary to interrogate how race, as a historically situated cultural formation, (re)shapes the boundaries of the state apparatus; that is, how racial thinking structures what falls within statecraft.

The concept of race ${ }^{4}$ has been a constitutive element of modernity and modern political institutions (Winant; Wimmer; Goldberg; Quijano), including the modern state administrative apparatus. That is, modern states and their apparatuses are inherently racial institutions. Not only did the world become modern as it took on racial configurations through conquest, nation-state formation, enslavement, and subjugation (Winant). Modern states were themselves conceived - conceptually and institutionally - through modern racial thinking as projects of racial configuration, as instruments of homogeneity against heterogeneous ways of being (Goldberg).

I conceptualize the ethnoracial bureaucracy as a racialized social system "that allocate[s] differential economic, political, social, and even psychological rewards to groups along racial lines; lines that are socially constructed" (Bonilla-Silva 474). In the ethnoracial bureaucracy, socio-historically situated ethnoracial meanings and hierarchies underpin state bureaucratic hierarchy and space. Racial ideology accompanies the bureaucracy's ethnoracial structure as a constitutive element of its relations and practices (Bonilla-Silva). Hence, the ethnoracial bureaucracy rests on two interrelated dimensions: structural and ideological.

The structural dimension of the ethnoracial bureaucracy is reflected in its ethnoracial composition, occupational segregation, and the racialization of the bureaucratic hierarchy (Acker). These entail organizational inequality in economic rewards, bureaucratic authority and decision-making, and various forms of symbolic capital, among other rewards. In addition, interactional and

\footnotetext{
${ }^{4}$ Rather than an essential or fixed trait, Howard Winant views race as an inherently modern phenomenon: "an organizational principle, a praxis and structure that has constructed and reconstructed world society since the emergence of modernity [...]" (Winant 19. emphasis in the original). He traces its historical emergence to the fifteenth century.
} 
physical tasks (re)produce state organizations as racialized spaces (Wingfield and Alston; Acker). However, we must consider not only intra-organizational dynamic of organization but also territorial bureaucratic structure. The racialization of composition, segregation, and hierarchy vary across levels of territorial administration, from the central state bureaucracy to municipalities.

The ideological dimension consists of schemes of knowledge through which individuals make sense of their world and act (Lamont and Molnár). Racial discourses and expressions rationalize as well as reinforce social relations and practice in society (see Quijano on race as a mental category) and, hence, the ethnoracial bureaucracy. For example, symbolic constructs of the political leadership and management, gendered and racialized, have coupled power with white, male and upper-middle class cultural registers (Puwar, "The Racialised Somatic Norm and the Senior Civil Service"). While erasing long histories of virtual Creole monopoly of the bureaucracy, such symbolic constructs naturalize the bureaucracy's ethnoracial structure and culture (see Bracey II on white institutional space), and deem ethnoracial and gendered others variously unfit for state bureaucratic practice (Puwar, Space Invaders; Vallas and Cummins). Importantly, the racial bureaucracy is not static but a site of ongoing social contestation.

\section{The Ethnoracial Composition of the State Bureaucracy in 2001}

As many of his speeches reveal, for President Morales the absence of Andean surnames marking indigeneity, like Condori or Mamani, in the bureaucracy's payroll exposes the coloniality of the Bolivian state. For example, during his first inauguration speech, he noted,

We have to put an end to the colonial state. Imagine, only after 180 years of democratic republican life, we [indigenous people] were able to get here. We can be in the Parliament. We can be in the presidency, in the mayoral offices. Before, we didn't have that right. [...] And that colonial state is still now in force. Imagine, it is not possible that in the National Army there is not a general [whose surname is] Condori, a General Villca, a General Mamani, a General Ayma. There aren't any yet. There it is, the colonial state.

A recent study on the social composition of the Bolivian bureaucracy shows that the majority of urban public sector employees between 1989 and 2012 are Spanish monolingual speakers (Soruco et al.). Based on survey data 
from the National Statistics Institute (INE), Spanish monolingual speakers, on average, accounted for 59.5 percent of public sector employment between 1989 and 2005, and 62.1 percent between 2006 and 2012. In rural areas, in turn, monolingual Spanish speakers are a minority. They accounted, on average, for 25.3 percent between 1996 and 2005, and 31.7 percent between 2006 and 2012. Notably, indigenous-language monolingual speakers generally accounted for less than 1 percent of public sector employment.

Soruco et al.'s analysis provides a useful sketch of the ethnoracial composition of public-sector employment in Bolivia. Yet, in this paper, I aim examine specifically the state's administrative apparatus, or public administration employment. Between 1989 and 2012, public administration represented between 25 and 45 percent of public sector employment (Soruco et al.). Moreover, in addition to zooming in on the public administration sector, I also examine the racialization of the occupational hierarchy within the bureaucracy. To provide a different approximation of the ethnoracial composition of the bureaucracy overall and across occupation groups prior to the Morales administration, I use individual-level data from the 2001 national census, particularly the IPUMS International 10\% sample (Minnesota Population Center).

I constrain my analysis to urban respondents who indicated public administration as their employment sector. By constraining the analysis to urban respondents, I attempt to distinguish between the central state bureaucracy and other territorial levels of the administrative apparatus. I discuss some of the limitations of this approach later. I also use three proxies for race/ethnicity in Bolivia: language ability, maternal language, and reported self-identification with an indigenous ethnic group. I use the three proxies because the rise of Spanish monolingualism among the increasingly urban indigenous-origin population in recent decades means that language ability is not as robust an indicator of ethnoracial social classification as in the past.

As I show in Table 1, based on the language ability criteria, I find that Spanish monolingual speakers accounted for 57.5 percent of public administration workers in urban areas. This is similar to the composition of the urban public sector overall, as reported in the aforementioned study (Soruco et al.). However, by disaggregating public administration employment by occupation, my analysis further reveals that the proportion of Spanish monolingual speakers was significantly higher among management, professionals, and clerical employees: nearly 70 percent. Instead, in low-level occupations in public administration, those who speak an indigenous language outnumber Spanish monolingual speakers nearly 2:1. 


\begin{tabular}{|c|c|c|c|c|c|c|}
\hline $\begin{array}{l}\text { Occupation } \\
\text { Group }\end{array}$ & \multicolumn{2}{|c|}{$\begin{array}{c}\text { Language } \\
\text { Spanish Indigenous }\end{array}$} & \multicolumn{2}{|c|}{$\begin{array}{l}\text { Mother Language } \\
\text { Spanish Indigenous }\end{array}$} & $\begin{array}{c}\text { Ethnic Group } \\
\text { Non-Indigenous } \\
\%\end{array}$ & $\begin{array}{l}\text { Indig. } \\
\%\end{array}$ \\
\hline Managers & 70.1 & 29.9 & 93.6 & 6.4 & 55.0 & 45.1 \\
\hline Professionals & 65.7 & 34.3 & 91.8 & 8.2 & 54.6 & 45.4 \\
\hline Clerks & 70.3 & 29.7 & 90.3 & 9.7 & 54.4 & 45.6 \\
\hline Service & 38.9 & 61.1 & 70.3 & 29.7 & 33.4 & 66.6 \\
\hline All & 57.5 & 42.5 & 84.0 & 16.0 & 47.0 & 53.3 \\
\hline $\mathrm{N}$ & 5,719 & & 5,719 & & 5,714 & \\
\hline
\end{tabular}

Table 1: Ethnoracial composition of the public administration sector in urban Bolivia in 2001 by occupation group, using different proxies for race/ethnicity Source: Instituto Nacional de Estadística de Bolivia 2001 Population and Housing Census (10\% sample). IPUMS, International

An alternative proxy for race/ethnicity in Bolivia is that of mother language, or the language a respondent learned to speak at home before the age of 5. Using this criterion, the disproportionate representation of indigenous Bolivians among those employed in public administration in urban areas prior to 2006 is more marked. The analysis reveals that those who grew up speaking only Spanish account for 84 percent of urban public administration employees. Among managers, professionals, and clerks, only 1 out of 10 employees reported an indigenous language as their maternal language. Among service occupations, respondents who reported an indigenous language as a mother language account for nearly 30 percent of employees.

Finally, in the 2001 census, INE asked Bolivians for the first time whether they belong to one of Bolivia's ethnic groups, such as Quechuas, Aymaras, or Guaranies, among others, or not. Using the ethnic self-identification criterion, 47 percent of urban public administration employees are non-indigenous, suggesting an indigenous-origin majority body of public administrators. However, examining the ethnoracial composition across the occupation ladder reveals that non-indigenous Bolivians account for nearly 55 percent of managers, professionals, and clerks. Among low-level workers in urban public administration, non-indigenous Bolivians account for only 33.4 percent of employees; indigenous-origin employees are the majority among low-level workers. The design of the ethnic self-identification question, however, generated much debate around its reliability as a measure of identity. 
Unfortunately, the analysis presented in Table 1 does not discriminate by level of government or particular cities, such as La Paz, where the bulk of the national bureaucracy concentrates. It is likely that in 2001, the proportion of indigenous bureaucrats was significantly lower in the national-level bureaucracy than at other government levels, especially rural municipalities. This is because the decentralization reforms of the 1990s led to an increased presence of indigenous men and women in municipal-level governments (e.g., Albó and Tacuri Quispe). Yet, these reforms did not bring a change of similar magnitude in the national bureaucracy, which only saw significant compositional changes under the Morales administration (Soruco et al.). Moreover, while this analysis provides an important approximation of the Bolivian bureaucracy as a racialized social system, less is known about the experiences of indigenous participation in the central state bureaucracy, or public administration, particularly its middle and upper echelons.

The ethnoracial composition of the state bureaucracy is "[...] the product of quite deliberate choices by political elites attempting to create and entrench state authority" (Enloe 343). Thus, in the next section, I examine the narratives of race and nation through which state elites advanced and rationalized a racialized public sphere and state bureaucracy.

\section{Race and State in Bolivia's Development}

After independence, Criollo state elites were at odds in reconciling new notions of citizenship with efforts to secure state power, reaffirm their racially determined status as whites, and control the indigenous labor force. In 1825, over 72 percent of its 1.1 million inhabitants were categorized as Indians; 18 percent, mestizos; and less than 1 percent, Afro-descendants (Bonilla). Less than one in ten Bolivians were criollos, or whites. The republican governments they created represented of only a small proportion of the population (Klein), namely the roughly 20 percent that could speak Spanish, the state language. ${ }^{5}$ Amidst a post-war crisis, Creole elites aimed to maintain local power relations, control social mobility, and finance the development of a state bureaucracy that could employ members of the elite and put resources extracted from indigenous populations at the service of elite projects (Irurozqui, "Tributo y Armas En Bolivia"; Klein; Larson, Trials of Nation Making).

\footnotetext{
${ }^{5}$ Only 7 percent of Bolivians were literate in Spanish in the 1840 s (Klein).
} 
Historical research on Bolivian nation-state building shows that the liberal-oligarchic state period, beginning in the 1880s, crystallized racial distinctions in the republic. Following the period of caudillismo, oligarchic Bolivian elites articulated an exclusionary criollo nation-state building project through which they aspired to "modernize" the country (Irurozqui, La armonía de las desigualdades; Larson, Trials of Nation Making). They established a limited-participation parliamentary regime, which legitimized their social position and granted them exclusive control over the public sphere and the bureaucracy (Irurozqui). At the turn of the century, government affairs shifted onto the hands of professional politicians, primarily educated lawyers, that "while committed to a liberal conception of parliamentary government and constitutional law, believed strongly in a caste system and rule by a white oligarchy" (Klein 159). In this context, less than 1 percent of the population enjoyed full political rights (Klein).

The late nineteenth century saw social Darwinism emerged as the main frame of reference for Creole elites (Demelas). It promised white elites progress and provided a coherent narrative to justify racial rule and inequality. Historian Marie-Danielle Demelas characterizes this discourse as follows: "The republic's instability [...] is not due to the ambition of bosses, the whims of the peoples or a birth curse; its cause is found in the racial composition of the country" ("Darwinismo a la criolla" 62). ${ }^{6}$ Thus, it attributed underdevelopment to Bolivia's racial heterogeneity, a feature they perceived absent in Western powers (Irurozqui, "'Desvío Al Paraíso'"; Larson, "Redeemed Indians, Barbarized Cholos"). While attributing the woes of the past and present to the purportedly inferior Indian and mixed races, they imagined a white future.

As state dependence on Indian tribute declined and urban demand for food and thus agricultural land and labor increased, Creole elites construed indigenous communities and mobilization as obstacles and threats to modernization. They also represented the mestizo and cholo populations that increasingly encroached their urban spaces and often met the criteria for citizenship as dangerous to order and progress and naturally incapable of freedom and democracy because of their purported degenerate mixed race (Demelas; Larson, "Redeemed Indians, Barbarized Cholos"). As Irurozqui notes, " $[t]$ hey were the antithesis of the progress and modernization they sought and,

\footnotetext{
${ }^{6}$ The translation of texts originally published in Spanish belongs to the author
} 
therefore, they could not be considered apt for a new Bolivia seeking to break with its backwardness" (La armonía de las desigualdades 17).

As social Darwinism began to lose legitimacy, Creole racial thinking moved into combinations of biologism, environmental determinism, and historicism. Thus, 1910 marks the emergence of a 'neocivilizing narrative,' in which whites emerged as an Indian-civilizing vanguard that would protect Indians against provincial mestizos, represented as parasitic and despotic, and urban cholos, construed as ignorant and politically volatile. Intellectuals and statesmen, like Alcides Arguedas, reimagined the Indian as a permanent feature of the country that could contribute to the country's modernization through rural labor but only under the auspices of authoritarian paternalism and differentiated education (Larson, "Redeemed Indians, Barbarized Cholos").

This emergent narrative naturalized the relationship between whiteness and modernity and whiteness and political-bureaucratic leadership. Creoles bestowed upon themselves the 'burden' of giving these populations gradual access to 'civilized life' and citizenship (Irurozqui, La armonía de las desigualdades). At the same time, it built on earlier themes: the supposed incompatibility of modernity and ethnoracial heterogeneity, and the purported unfitness of the subaltern races.

In the 1930s, the oligarchic state weakened in the face of emergent alternative projects and growing demands to expand the political arena (Klein). Traditional beliefs within the white ruling classes began to erode as Marxist thought made its way into the universities, and labor and indigenous mobilizations gained national attention (Klein). In this context, new parties emerged that put labor issues and indigenous servitude at the center of political debate (Klein). As the public sphere expanded, the efforts of the traditional oligarchy to maintain control of the bureaucracy and suppress labor and indigenous mobilizations ultimately catalyzed the 1952 Revolution from which the MNR emerged as the ruling party. Primarily comprising of whitemestizo politicians and mestizo leaders of the workers' movement (Klein), the MNR effectively extending universal citizenship by abolishing the literacy requirement and abolished indigenous service obligations (Klein). They also reimagined the state in positive terms, now becoming a guarantor of the population's welfare through the extension of health and education services and playing an active role in the economy (Klein).

The revolution abolished de jure political ethnoracial discrimination, but post-revolutionary white-mestizo elites reinscribed race into the political system in new ways. The popular new nation-building project rested 
on a paternalistic gaze of the Indian still in need of civilization and modernization (Canessa). While adopting mestizaje and indigenismo discourses and projects, indigenous acquisition of citizenship "was accompanied by powerful assimilationist policies that sought to turn 'indians' into 'Bolivians,' leaving little space for any expression of indian or indigenous identity" (Canessa 15). Mestizaje in this particular context revalorized past indigenous civilizations, but consisted primarily of whitening through assimilation into the dominant class culture (Canessa). The possibility of personal and racial improvement depended on the maintenance of a rigid racial hierarchy on which 'improvement' depended (Canessa). As sociologist Esteban Ticona Alejo notes, despite opening up social mobility opportunities for indians, cholos, and mestizos, the revolution did not change the contours of highly racist social system (Organización y liderazgo aymara).

These narratives were evident in various actions taken by the MNR. The imposition of the campesino category sought to facilitate national integration through state-led assimilation (Albó, “And from Kataristas to MNRistas?" 66). Land reform hoped to end the ayllu, demobilize the indigenous movement, and modernize agriculture (Ticona Alejo, Organización y liderazgo aymara). Educational reforms were primarily concerned with assimilation into Westernized, Spanish-speaking white-mestizo mores and behaviors (Canessa). Finally, while the historically excluded gained political influence, the corporatist system meant that white-mestizo elites controlled the central state bureaucracy, while indigenous peasants and mestizo workers partook in national politics primarily through unions (Albó, "And from Kataristas to MNRistas?").

Post-revolutionary reforms helped crystallize a state ideology that viewed race and racism as playing no longer any role in Bolivian society. This is evident, for example, in Bolivia's reports to the United Nations Committee against Racial Discrimination in the 1970s and 1980s. In them, officials argued that universal citizenship had effectively addressed ethnoracial discrimination in the country (Comité Nacional Contra el Racismo y Toda Forma de Discriminación). During the eighteen years of military rule, the army maintained assimilation policies and advanced an authoritarian modernization project. Overtime, they came to view the increasing demands of the indigenous peasant unions as an obstacle to development, responding with violent repression (Ticona Alejo, Organización y liderazgo aymara).

In the 1990s, in the context of a multicultural and neoliberal turn in Latin America, the consolidation of a national indigenous movement changed 
indigenous subjectivity and politicized ethnoracial exclusion in the country (Yashar). The movement and identity consolidated around demands for recognition and the reform of the 'difference-blind' state into a pluricultural one (Van Cott). This change can be partly traced back to a young generation of Aymara indigenous Bolivians that formed the Indianista and Katarista movements in the 1970s. In the face of an assimilationist nation-state project, they advocated for a multinational state, indigenous political autonomy, and the need to overcome neocolonial structures of racial and class oppression (Albó, "Bolivia: From Indian and Campesino Leaders to Councillors and Parliamentary Deputies"). They also sought to gain access to power through alliances with white-mestizo parties (Ticona Alejo, Organización y liderazgo aymara).

In a shifting economic and political context, Bolivia underwent significant reforms in the 1990s intended to promote economic growth and deepen democracy. The indigenous movement secured constitutional recognition of indigenous authorities, customary law, and special indigenous jurisdictions with specific politico-administrative competencies (Sieder). Fiscal and limited administrative decentralization reforms, in turn, created local-level governments, participatory institutions, and a more equal distribution of public investment across the territory. The reforms created formal political channels for groups, including indigenous communities and peasant communities, to make demands on the state at the local level (Kohl and Farthing). These undermined the corporatist political system (Postero) and helped indigenous participation in local-level government rise meteorically (Albó and Tacuri Quispe).

These reforms did reconfigure the relationship between state and indigenous people, albeit only in limited ways (Van Cott). In dominant national ideas of nation, including multiculturalism, indigenous leaders represented the particular, namely indigeneity and difference, while white-mestizo leaders stood for the universal. In fact, while containing "indigenous issues" within local governments and islands in the central state bureaucracy, state elites insulated the rest of the state bureaucracy from ethnoracial politics. At the central-level, access to the bureaucracy was still granted to indigenous and cholos only in very restricted spaces of governance, such as agricultural and labor matters, and mostly in the framework of electoral or appeasement strategies.

In sum, while the racial paradigms underpinning the narratives of nation and modernity that informed the state building projects of the white elites 
have changed, their basic themes have been astoundingly durable. Dominant narratives in Bolivia have variously attributed economic and political underdevelopment to its ethnoracial heterogeneity, and particularly its purported 'indian problem.' They also portrayed white and white-mestizo elites as carriers of modernity and natural holders of state power. Tórrez et al.'s study of elite representations of indians and cholo mobilizations in the press between 1899 and 2003 shows in exhaustive detail the continuity of representations of indigenous Bolivians as backward, easilymanipulated, and intellectually hindered (Tórrez Rubín de Celis et al.). These ideologies not only help constitute and rationalize the Bolivian ethnoracial order. They also help constitute and rationalized an ethnoracial state bureaucracy.

\section{Decolonization and Changing Narratives of Race and State}

Decolonization in Bolivia is a transformational and democratizing force in society that promotes the total elimination of racial and cultural discrimination, advances the recognition and strengthening of knowledges, know-how, and science of indigenousnative-peasant nations and peoples and the urban population, recovering the most positive aspects of modern and western society. (PDES 9)

In this section, I turn my attention to the decolonization discourse, which $I$ argue offers alternative narratives of race and nation that undermine the naturalization of political leadership in Creole and white-mestizo Bolivians and, hence, contest the material and ideological dimensions of the ethnoracial bureaucracy. Decolonization proponents understood it necessary for the project's success to decenter the Hispanicizing monocultural project that the elite had advanced through the state. They noted, "To decrease the centrality of the dominant culture is imperative for decolonization because colonial heritages rest on ethnoracial representations, discourses, and ideological structures. The nerve center of coloniality is control of language and knowledge" (PND 16). Control of the central bureaucracy enabled MAS-IPSP leaders and intellectuals to produce and mobilize new official interpretations of Bolivia's development. 
Government documents in which decolonization proponents laid out their tenets and strategy ${ }^{7}$ reveal that the official decolonization discourse offers a rearticulation of the relationship between race and the nation-state in the country's past and future. First, the state decolonization discourse contests the 'indian problem' trope of the twentieth century ruling elites. Instead, it posits that elite investment in a neocolonial order constitutes the root cause of Bolivia's underdevelopment. Second, it rejects the ethnoracially homogenizing state of the previous century in favor of an inherently heterogeneous 'plurinational state.' Lastly, it redefines the symbolic places of indigeneity and whiteness in the indigenist mestizaje that creeped into the elite state project following the Revolution of 1952. Decolonization, thus, seeks to redraw the symbolic and material boundary between statecraft and indigeneity.

In the official decolonization discourse, colonialism emerges as the primary force shaping the post-colonial history of the body politic. For example, the 2006-2010 National Development Plan notes that "[t]he theoretical framework of this [development] strategy is based on the conviction that the limitations and frustrations of the country's development are the product of an ethnic, cultural and political domination system steeped in racism and rooted in various forms of colonialism" (PND 12). Thus, decolonization proponents enunciate a 'colonial problem' that problematizes the power relations and essentializing racial narratives that shaped the boundaries of citizenship and national belonging, as well as the racialization of the state bureaucracy.

The 'colonial problem' also underlines the investment of criollo and whitemestizo elites and the global capitalist system in an ethnoracial order enforced and reproduced through the state. Here, Creole elites created a state fundamentally based on ethnoracial inequality. The unequal design of the state was not a passive continuation of colonial society but an actively advanced Creole racial formation project. In this historical narrative, non-indigenous elites reconstituted 'colonial republicanism' over time in: the late nineteenth century, the Revolution of 1952, and the neoliberal period. For the decolonization proponents then Bolivia's underdevelopment is therefore not the result of an 'indian problem' but that of a colonial. Underdevelopment has its locus not on indigenous culture but on a deeply engrained racialized social system.

\footnotetext{
${ }^{7}$ These include the MAS-IPSP government programs for 2006-2010, 2010-2015, and 20152020; the 2006 National Development Plan; the 2016 Social and Economic Development Plan; and President Evo Morales Ayma's inauguration speeches; among many others.
} 
The enunciation of a 'colonial problem' as the root-cause of Bolivian underdevelopment problematizes a second central precept of twentiethcentury dominant narratives of race and modernity. It undermines the symbolic Indian-modernity antitheses, which construes whiteness is civilization and future, and indigeneity, and proximity to it, as backwardness. The decolonization discourse, in turn, reclaims indigeneity from this hegemonic white-mestizo gaze, rearticulating its meaning vis-à-vis modernity. Through (often romantic) descriptions of indigenous practices and epistemologies, decolonization proponents attributed indigeneity positive values, and vilified particular values that Western-oriented white-mestizo elites historically had purportedly embraced and promoted. For example, whereas Western liberalism and capitalism are buttressed by the values of "individualism" and "competition," indigenous social relations and political organization rest on "solidarity" and "complementarity."

The decolonization discourse seeks to revalorize indigeneity not only at the margins of the nation-building project, but as the foundation of a new national identity and state institutionality. Indigenous peoples and peasants thus emerge as "the legitimate historic promoters of a democratic transformation in the exercise of political power" (PND 12-13). That is, this majority population previously represented as lacking, if not incapable of, a modern political project emerges as a historical agent of change and architect of modern institutions. Yet, careful to reaffirm inclusionary objectives and rejecting ethnocentrism, proponents also noted that this "does not mean to substitute a seigniorial hegemony with an indigenous one" (PND 16), but to expand the forms and institutions of modernity and to democratize the state.

The third break with the precepts of the dominant narrative of race and modernity mobilized by white-mestizo elites in the twentieth century relates to the ethnoracial heterogeneity, which modernizing elites had variously conceived as an obstacle to development. In the codified MAS decolonization project, harnessing the country's heterogeneity laid the foundation for the transformation of the nation-state transformation and an institutionality that is based on "the expression of diversity instead of homogeneity" (PND 78). The 2006-2010 PND explains that "[t]his [development] process seeks to improve and expand human choices, conditions, and capacities on the basis of respect for difference without homogenizing communities, peoples, and individuals, but instead strengthening their cohesion through heterogeneity" (PND 12, emphasis added). To change a colonial system, it is necessary to "[suppress] 
the current structure of colonial domination and racial discrimination" through interculturality, understood as the opposite of ethnocentrism (PND 14).

Thus, in the decolonization discourse heterogeneity emerges as a force and requisite for dismantling the state's colonial structures. Importantly, this discursive rearticulation of heterogeneity/homogeneity problematized the ethnoracial foundations and homogenizing force of the state apparatus and its agents. The inherited state apparatus embodies and advances this homogenizing project. It is understood both as an institution and actor shaped by a small elite, whose interests depend on the ethnoracial order. Moreover, in the decolonization critique, the bureaucracy and its agents are understood to reproduce the colonial homogenizing state through their quotidian administrative operations, actively repressing and excluding indigenous experiences and practices.

Yet, while the state can be a tool of domination, the decolonization proponents did not conceive this as inescapable. In their view, the state could become a tool for liberation. If captured and deeply reformed, culturally and structurally, the apparatus has the potential to transform the social order because it has the power to legislate and regulate, to distribute resources, to name, count and recognize, and to produce culture and promote values, significantly altering the life conditions of marginalized and excluded Bolivians. ${ }^{8}$ For this reason, the project proposed more than only the inclusion of the formerly excluded in state spaces: "[t]o achieve this objective [to democratize the state] it is crucial to change the current constitutive foundations of power and the current policies, and to incorporate in spaces of power, in the national decisions and public administration, indigenous peoples, peasants and social movements" (PND 81). That is, it questioned not only the exclusion of indigenous men and women from the state bureaucracy and its monopoly by a small non-indigenous segment of the population, but also the racist foundations of its institutional logics.

State decolonization thus proposes to transform the state in several dimensions. First, it calls for a radical transformation state structure, arguing for a territorial-administrative reconfiguration as well as for a new constitution. Second, it proposes to transform the state as actor in policy and the economy. On the one hand, the state should redistribute economic and symbolic

\footnotetext{
8 This was not the only understanding of the state put forward by national theorists of decolonization. In fact, others viewed decolonization and the state as contradictory calling to move beyond the state form (see Gosálvez and Dulon).
} 
resources through new policies that favor the most socially disadvantaged and excluded segments of society. On the other, a radical democratization of the state should enable citizen participation in all areas of policymaking, spaces of decision-making, and monitoring mechanisms. Third, the project proposes a transformation of the state as organization, proposing changes to composition and the logic of public administration, which entails a deep politicization of what legitimately, constitutes bureaucratic expertise, practice, and technology.

\section{Conclusion}

In this paper, I have conceptualized the ethnoracial state bureaucracy and discussed the racialization of the central state bureaucracy in Bolivia along its material and ideological dimensions. I argued that the state decolonization project problematizes the racialization of the state bureaucracy and mobilizes oppositional narratives of race and nation to contest it. Having examined the ethnoracial composition of the central state bureaucracy's spaces and hierarchy in 2001, I then discussed the racial ideologies through which state elites historically drew and rationalized the material and symbolic boundary between indigeneity and state bureaucracy. In particular, I identified the endurance of particular themes in the nation-state building projects of the criollo and white-mestizo elites: the incompatibility between ethnoracial heterogeneity and modernity, the unfitness of Indians and cholos for the public sphere, and the white-civilization metonymy. By contrast, in contemporary Bolivia, new state elites have sought to decenter a Hispanicizing monocultural state logic. The official decolonization discourse: 1) contested the 'indian problem' trope, attributing underdevelopment to a neocolonial order; 2) rejected the homogenizing state in favor of an inherently heterogeneous state as the necessary basis for development; and 3) reclaimed and revalorized the role of indigeneity in the nation-state project, placing it at its center.

The Bolivian state decolonization project and the renegotiation of the ethnoracial boundaries of the state bureaucracy that it has unleashed are contested and ongoing processes. While indigenous movements had variously problematized indigenous exclusion, agents of the state historically confined their demands only to limited areas of the apparatus, such as indigenous and peasant affairs agencies and local governments and jurisdictions. The hegemonic rise of a state-sanctioned, but oppositional ethnoracial project has notably altered indigenous access to the state bureaucracy and the terms of inclusion. This is because alongside ethnoracial recomposition, decolonization 
has problematized bureaucratic practice and its ethnoracial foundations and logics, previously insulated from racial politics under the veil of universality. Yet, the government's efforts to codify the decolonization of public administration and the civil service into law have been slow. The durability of the project is not guaranteed as the sediment of history and competing political projects weighs heavy on this process of transformation and negotiation.

\section{Works Cited}

ACKER, Joan. 2006. "Inequality Regimes Gender, Class, and Race in Organizations." Gender \& Society 20(4): 441-464.

ALBÓ, Xavier. 1994. "And from Kataristas to MNRistas? The Surprising and Bold Alliance between Aymaras and Neoliberals in Bolivia." Indigenous Peoples and Democracy in Latin America. Donna Lee Van Cott, ed. New York: St. Martin's Press. 55-82.

---. 2002. "Bolivia: From Indian and Campesino Leaders to Councillors and Parliamentary Deputies." Multiculturalism in Latin America: Indigenous Rights, Diversity and Democracy. Rachel Sieder, ed. Basingstoke: Palgrave Macmillan UK. 74-102.

---. $\quad$ and Víctor Tacuri Quispe. 2004. Quiénes son Indígenas en los Gobiernos Municipales. Plural Editores/CIPCA.

BONILLA, Heraclio. 1997. "Estructura y articulación política de las comunidades indígenas de Los Andes Centrales con sus estados nacionales." La Reindianización de América. Siglo XIX. Leticia Reina, ed. México: Siglo XXI Editores/CIESAS. 93-108.

BONILLA-SILVA, Eduardo. 1997. "Rethinking Racism: Toward a Structural Interpretation." American Sociological Review 62(3): 465-480.

BRACEY II, Glenn E. 2015. "Toward a Critical Race Theory of State." Critical Sociology 41(3): 553-572.

CANESSA, Andrew, ed. 2005. Natives Making Nation: Gender, Indigeneity, and the State in the Andes. Tucson, AZ: University of Arizona Press.

CÁRDENAS, Víctor Hugo. 2011. "Participación política indígena y políticas públicas para pueblos indígenas en Bolivia." Participación política indígena y políticas públicas para pueblos indígenas en América Latina. Beatriz Cajías de la Vega, ed. La Paz: Konrad Adenauer Stiftung. 17-64.

COMITÉ NACIONAL CONTRA EL RACISMO Y TODA FORMA DE DISCRIMINACIÓN. 2012. "Anexo 2: Marco normativo internacional y nacional contra el racismo y la discriminación." Política del Estado Plurinacional de Bolivia contra el racismo y toda forma de discriminación. La Paz: Ministerio de Culturas del Estado Plurinacional de Bolivia.

DEMELAS, Marie-Danielle. 1981. "Darwinismo a la criolla: El darwinismo social en Bolivia, 1880-1910." Historia Boliviana 1(2): 55-82. 
ENLOE, Cynthia H. 1978. "Ethnicity, Bureaucracy and State-Building in Africa and Latin America." Ethnic and Racial Studies 1(3): 336-351.

GOLDBERG, David Theo. 2002. The Racial State. Oxford: Blackwell Publishers.

GOSÁLVEZ, Gonzalo, and Jorge Dulon, eds. 2010. Descolonización en Bolivia: Cuatro ejes para comprender el cambio. La Paz: Vicepresidencia del Estado Plurinacional de Bolivia y Fundación Boliviana para la Democracia Multipartidaria.

GOTKOWITZ, Laura. 2011. "Introduction: Racism of the Present and the Past in Latin America." Histories of Race and Racism: The Andes and Mesoamerica from Colonial Times to the Present. Laura Gotkowitz, ed. Durham, NC: Duke University Press. 1-56.

HTUN, Mala. 2016. Inclusion Without Representation in Latin America: Gender Quotas and Ethnic Reservations. Cambridge, UK; New York: Cambridge University Press.

IRUROZQUI, Marta. 1994. La armonía de las desigualdades: Elites y conflictos de poder en Bolivia, 1880-1920. Madrid; Cusco: Consejo Superior de Investigaciones Científicas.

---. 2001. “'Desvío al Paraíso': Citizenship and Social Darwinism in Bolivia, 1880-1920." Reception of Darwinism in the Iberian World: Spain, Spanish America and Brazil. Thomas F. Glick et al., eds. Boston, MA; London: Kluwer Academic Publishers, 2001. 205-228.

---. 2012. "Tributo y armas en Bolivia. Comunidades indígenas y estrategias de visibilización ciudadana, siglo XIX." Mundo Agrario 13(25) [http://www.scielo.org.ar/scielo.php?script=sci_arttext\&pid=S151559942012000200010] página descargada el 2 de diciembre, 2019.

KLEIN, Herbert S. 2011. A Concise History of Bolivia. Cambridge, UK; New York: Cambridge University Press, 2011.

$\mathrm{KOHL}$, Benjamin, and Linda Farthing. 2006. Impasse in Bolivia: Neoliberal Hegemony and Popular Resistance. London; New York: Zed Books.

---. $\quad$ and Rosalind Bresnahan. 2010. "Introduction Bolivia under Morales: National Agenda, Regional Challenges, and the Struggle for Hegemony." Latin American Perspectives 37(4): 5-20.

LAMONT, Michèle, and Virág Molnár. 2002. "The Study of Boundaries in the Social Sciences." Annual Review of Sociology 28(1): 167-195.

LARSON, Brooke. 2004. Trials of Nation Making: Liberalism, Race, and Ethnicityin the Andes, 1810-1910. Cambridge, UK; New York: Cambridge University Press, 2004.

---. 2005. "Redeemed Indians, Barbarized Cholos: Crafting Neocolonial Modernity in Liberal Bolivia, 1900-1910." Political Cultures in the Andes 1750-1950. Nils Jacobsen and Cristóbal Aljovín de Losada, eds. Durham, NC: Duke University Press. 230-252.

MARAVIĆ, Patrick von, et al., eds. 2013. Representative Bureaucracy in Action: Country Profiles from the Americas, Europe, Africa and Asia. Cheltenham, UK; Northampton, MA: Edward Elgar.

MINNESOTA POPULATION CENTER. 2017. Integrated Public Use Microdata Series, International: Version 6.5. University of Minnesota. 
PDES. Plan de Desarrollo Económico y Social 2016-2020 en el Marco del Desarrollo Integral para Vivir Bien. 2015. La Paz: Estado Plurinacional de Bolivia.

[http://www.fndr.gob.bo/bundles/fndrdemo/downloads/pdes/pdes20 16-2020.pdf] página descargada el 2 de diciembre, 2019.

PND (PLAN NACIONAL DE DESARROLLO). 2007. Bolivia Digna, Soberana, Productiva y Democrática para Vivir Bien. Lineamientos Estratégios 2006-2011. La Paz: Gaceta Oficial de Bolivia.

[http://www.ademaf.gob.bo/normas/ds29272.pdf] página descargada el 2 de diciembre, 2019.

POSTERO, Nancy. 2006. Now We Are Citizens: Indigenous Politics in Postmulticultural Bolivia. Standord, CA: Stanford University Press.

PUWAR, Nirmal. 2001. "The Racialised Somatic Norm and the Senior Civil Service." Sociology 35(3): 651-670.

---. 2004. Space Invaders: Race, Gender and Bodies Out of Place. Oxford and New York: Bloomsbury Academic.

QUIJANO, Aníbal. 2000. "Coloniality of Power and Eurocentrism in Latin America." International Sociology 15(2): 215-232.

SIEDER, Rachel. 2002. "Introduction." Multiculturalism in Latin America: Indigenous Rights, Diversity, and Democracy. Rachel Sieder, ed. New York: Palgrave Macmillan 1-23.

SORUCO, Ximena, et al. 2014. Composición social del Estado Plurinacional: Hacia la descolonización de la burocracia. La Paz: Centro de Investigaciones Sociales, Vicepresidencia del Estado.

STEINMETZ, George. 1999. "Introduction: Culture and the State." State/Culture: State-Formation after the Cultural Turn. George Steinmetz, ed. Ithaca, NY: Cornell University Press 1-49.

TICONA ALEJO, Esteban. 2000. Organización y liderazgo aymara: La experiencia indígena en la política boliviana, 1979-1996. La Paz: Universidad de la Cordillera.

---. 2010. Saberes, conocimientos y prácticas anticoloniales del pueblo aymara-quechua en Bolivia. La Paz: Plural Editores.

TÓRREZ RUBíN DE CELIS, Yuri, et al. 2010. El indio en la prensa: Representación racial de la prensa boliviana con respecto a los levantamientos indígenas/campesinos (1899-2003). Cochabamba: Centro Cuarto Intermedio.

VALLAS, Steven P., and Emily Cummins. 2014. "Relational Models of Organizational Inequalities: Emerging Approaches and Conceptual Dilemmas." American Behavioral Scientist 58(2): 228-255.

VAN COTT, Donna Lee. 2008. Radical Democracy in the Andes. Cambridge, New York: Cambridge University Press.

WADE, Peter. 2010. Race and Ethnicity in Latin America. London; New York: Pluto Press.

WIMMER, Andreas. 2002. Nationalist Exclusion and Ethnic Conflict: Shadows of Modernity. Cambridge, New York: Cambridge University Press.

WINANT, Howard. 2001. The World Is a Ghetto: Race and Democracy Since World War II. New York: Basic Books, 2001. 
WINGFIELD, Adia Harvey, and Renée Skeete Alston. 2014. “Maintaining Hierarchies in Predominantly White Organizations: A Theory of Racial Tasks." American Behavioral Scientist 58(2): 274-287.

YASHAR, Deborah J. 2005. Contesting Citizenship in Latin America: The Rise of Indigenous Movements and the Postliberal Challenge. Cambridge, New York: Cambridge University Press.

$(\mathrm{cc}) \mathbf{E Y}$

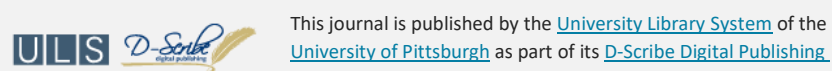
Program, and is cosponsored by the University of Pittsburgh Press. 